\title{
Bio-efficacy of Pre- and Post-emergence Herbicides for Weed Management in Linseed (Linum usitatissimum L.) under Irrigated Conditions
}

\author{
Gaurav Mahajan $^{1^{*}}$ and Deepak Khande ${ }^{2}$ \\ ${ }^{1}$ AICRP on Maize, ${ }^{2}$ AICRP on Wheat, Zonal Agricultural Research Station, \\ J.N.K.V.V, Powarkheda, M.P. 461110, India \\ *Corresponding author
}

A B S T R A C T

Ke y w o r d s
Herbicide, Linseed,
Pre- and post-
emergence, Weed
management

\section{Introduction}

Owing to its various uses and special qualities, Linseed (Linum usitatissimum L.) occupies a greater importance among oilseeds. Under Indian agricultural conditions, it is grown mainly for extracting oil. The oil content of the seed varies from $33-47 \%$. Linseed oil is excellent dyeing oil used in manufacturing paints and varnishes, oilcloth, waterproof fabrics and linoleum and as edible oil in some areas. Linseed is also used in making paper and plastics. That is why it is also known as plastic crop. Linseed is more viewed as a health crop and is an excellent vegetarian source of Omega-3 fatty acids. Linseed crop is also grown for its fiber. In India linseed is cultivated in about 293 thousand hectares with a contribution of 142 thousand tones to the annual oilseed production of the country. Its average productivity is $484 \mathrm{~kg} / \mathrm{ha}$. Madhya Pradesh has largest growing area (64.5 lakh ha) and production (95 lakh tones) with $147 \mathrm{~kg} / \mathrm{ha}$ productivity (Anonymous 2019). Among several factors affecting linseed production, weeds infestation is a major factor. Yield losses due to weed infestation in linseed were 36\% (Mahajan, 2018). Weeds compete with crop plants for water, nutrients, space and 
light. The adverse effect of weeds can be minimized if few weeds are present but heavy infestation may cause complete crop failures. So, the present study was aimed to find out the efficacy of pre and post emergence herbicides for weed management in linseed.

\section{Materials and Methods}

The study was conducted during two consecutive Rabi seasons of 2017 and 2018 at Agricultural Research Farm, Powerkheda, Madhya Pradesh. The experiment field is situated on the banks of the holy river Narmada at $77^{\circ} .42$ ' $\mathrm{N}$ Latitude, $22^{\circ} .40$, E Longitude and $299 \mathrm{~m}$ above mean sea level. Total annual rainfall is about 39 inches (980 $\mathrm{mm}$ ) and more than $75-80 \%$ generally occurs during the monsoon season (JuneSeptember).The soil of the experimental field was mixed red and black with clay loam in texture and slightly alkaline in reaction with $\mathrm{pH}$ 7.7, EC 0.32 dS \m having organic carbon 0.61 per cent and available nitrogen 270 $\mathrm{kg} \backslash$ ha, phosphorus $16.4 \mathrm{~kg} \backslash \mathrm{ha}$ and potassium $352 \mathrm{~kg}$ hha at $0-15 \mathrm{~cm}$ soil depth. The experiment was laid out in randomized block design with ten treatments viz: Weedy Check $\left(\mathrm{T}_{1}\right)$, Hand Weeding (20 DAS) and 40 DAS $\left(\mathrm{T}_{2}\right)$, Metribuzen @ 250g/ha + Oxyflorfen @ $125 \mathrm{~g} / \mathrm{ha}$ (Pre emergence) $\left(\mathrm{T}_{3}\right)$, Pendimethalin @ $1 \mathrm{~kg} / \mathrm{ha}$ (Pre emergence) $f b$ Metsulfuron methyl @ 4g/ha at 25 DAS (Post emergence) $\left(\mathrm{T}_{4}\right)$, Imazethapyr 10EC @ 75g /ha at 2-3 leaf stage of weeds (Post emergence) $\left(\mathrm{T}_{5}\right)$, Oxyflourfen @ $125 \mathrm{~g} / \mathrm{ha}$ at 2-3 leaf stage of weeds (Post emergence) $\left(\mathrm{T}_{6}\right)$, Metsulfuron methyl @ $4 \mathrm{~g} / \mathrm{ha}$ at 2-3 leaf stage of weeds (Post emergence) $\left(\mathrm{T}_{7}\right)$, Isoproturon @ $1 \mathrm{~kg} / \mathrm{ha}$ at 2-3 leaf stage of weeds (Post emergence) $\left(\mathrm{T}_{8}\right)$, Isoproturon @ $1 \mathrm{~kg} / \mathrm{ha}+$ Metsulfuron methyl @ $4 \mathrm{~g} / \mathrm{ha}$ at 2-3 leaf stage of weeds (Post emergence) ( $\left.\mathrm{T}_{9}\right)$ and Oxadiargyl @ 80g/ha at 2-3 leaf stage of weeds (Post emergence) ( $\left.\mathrm{T}_{10}\right)$ with three replications. A uniform dose of $40 \mathrm{~kg} \mathrm{P}_{2} \mathrm{O}_{5}$ and $20 \mathrm{~kg} \mathrm{~K}_{2} \mathrm{O}$ was applied through single super phosphate and muriate of potash, respectively. The nitrogen $(80 \mathrm{~kg})$ was applied through urea in three split doses. Half dose of nitrogen and full doses of phosphorous and potassium were applied as basal at sowing and remaining half dose of nitrogen was applied in two equal splits i.e. at flowering and grain filling stage of the crop. For weed studies, weed dry weight was recorded (at $20 \& 80$ days stage) from $0.25 \mathrm{~m}^{-}$ 2 areas by placing a quadrate of $0.5 \times 0.5 \mathrm{~m}$ randomly at three places in border rows of each plot. Final data was expressed as number of weeds per square meters. The original values were subjected to square root transformation $(\mathrm{Y}=\sqrt{\mathrm{x}}+1)$ for statistical analysis. The net plot area was harvested manually at the maturity and the seed yield was recorded. Weed control efficiency (WCE) and weed index (WI) were calculated by the following method.

$$
\operatorname{WCE}(\%)=\frac{\mathrm{WCC}-\mathrm{WCT}}{\mathrm{WCC}} \times 100
$$

Where,

WCC $=$ Dry weight of weeds in unweeded control plot (g)

WCT $=$ Dry weight of weeds in treated plot (g)

$$
\text { Weed Index }=\frac{X-Y}{X} X 100
$$

Where,

$\mathrm{X}=$ Seed yield in weed free check plot $\left(\mathrm{kg} \mathrm{ha}^{-1}\right)$

$\mathrm{Y}=$ Seed yield in treated plot $\left(\mathrm{kg} \mathrm{ha}^{-1}\right)$

\section{Results and Discussion}

As the present study was aimed to find out the efficacy of pre and post emergence herbicides for weed management in linseed. The results are being discussed on the basis of 
performance of chemical treatments applied. The treatments weedy check $\left(\mathrm{T}_{1}\right)$ and hand weeding $\left(\mathrm{T}_{2}\right)$ were included for comparison and hence not discussed in details.

\section{Effect on crop}

The results from the present experiment clearly indicate that apart from mechanical weeding, the chemicals used for weed management had a significant effect on growth and yield attributes of crop during both the years of study (Table 1). Amongst the chemical methods of weed management, $\mathrm{T}_{4}$ (Pendimethalin @ $1 \mathrm{~kg} / \mathrm{ha}$ (PRE) + Metsulfuron methyl @ 4g/ha at 25 DAS (POS)) recorded significantly maximum plant height. Whereas, the application of Oxyflourfen@125 g/ha at 2-3 leaf stage of weeds (POS) $\left(\mathrm{T}_{6}\right)$, recorded the minimum plant height. This might be owing to availability of proper space between plants and less weed competition during initial stages of plant growth. The present findings corroborate with those of Bhatt et al., (2020).

The mean data of two experimental years revealed that among the measures of weed management, $\mathrm{T}_{4}$ (Pendimethalin @ $1 \mathrm{~kg} / \mathrm{ha}$ (PRE) + Metsulfuron methyl @ 4g/ha at 25 DAS (POS)) proved significantly superior in terms of all growth and yield attributing characters viz: higher number of branches per plant, number of capsules per plant, number of seed per capsules and test weight of grains at harvest except final plant population $(000 / h a)$. It was due to the fact that preemergence application of pendimethalin controlled the weeds from the very beginning, reducing crop-weed competition for nutrients, moisture, space and light.

This was followed by application of metsulfuron methyl which controlled the emerging and remaining weeds and created favorable conditions for crop growth by reducing competition further decay of weeds also resulted in improving soil aeration and water holding capacity. The present results agree with those of Tripathi et al., (2016).

Yield is the final expression of all the physiological and biochemical processes going on during the crop life cycle and has a direct relationship with the growth and yield attributing characters of plants. Amongst the weed management practices, application of Pendimethalin @ $1 \mathrm{~kg} / \mathrm{ha}$ (PRE) + Metsulfuron methyl @ 4g/ha at 25 DAS (POS) $\left(\mathrm{T}_{4}\right)$ proved the most beneficial which produced the significantly higher grain $(1425.3 \mathrm{~kg} / \mathrm{ha})$ next to hand weeding twice. The control (weedy) treatment brought about the significantly lowest productivity parameters.

All these weed management treatments reacted exactly in accordance with the growth and yield-attributing characters brought out by these treatments. The most advantageous factor associated with $\mathrm{T}_{4}$ treatment was that the Pendimethalin controlled the weeds from the very beginning of the plant growth and thereafter control of further emerging or remaining weeds was monitored by following the post emergence application of metsulfuron methyl, thus providing the almost weed-free condition for the actively growing crop plants. These results are in close agreement with those of Kumar et al., (2017).

\section{Effect on weeds}

The major weed species present in the experimental field were Amaranthus viridis, Brachiaria eruciformis, Eragrostis sp., Pennisetum pedicellatum, Cyperus rotundus, Cynodon dactylon, Cyperus irria, Echinochloa crusgalli, Euphorbia geniculata, Euphorbia hirta, Chrozophora rotleri predominantely. 
Table.1 Effect of different herbicides on growth, yield attributes and yield of linseed under irrigated conditions. (Mean of two years)

\begin{tabular}{|c|c|c|c|c|c|c|c|c|}
\hline & Treatment & $\begin{array}{l}\text { Plant } \\
\text { height } \\
(\mathbf{c m}) \text { at } \\
\text { harvest }\end{array}$ & $\begin{array}{c}\text { Number of } \\
\text { branches } \\
\text { per plant at } \\
\text { harvest }\end{array}$ & $\begin{array}{l}\text { Number of } \\
\text { capsules } \\
\text { per plant } \\
\text { at harvest }\end{array}$ & $\begin{array}{l}\text { Number } \\
\text { of seed } \\
\text { per } \\
\text { capsules }\end{array}$ & $\begin{array}{l}\text { Final plant } \\
\text { population } \\
(000 / h a)\end{array}$ & $\begin{array}{c}\text { Test } \\
\text { weight }\end{array}$ & $\begin{array}{l}\text { Seed yield } \\
\text { (kg/ha) }\end{array}$ \\
\hline $\mathbf{T}_{1}$ & Weedy Check & 46.13 & 1.00 & 14.53 & 6.0 & 1628 & 6.9 & 1087.6 \\
\hline $\mathbf{T}_{2}$ & Hand Weeding 20 DAS and 40 DAS & 59.73 & 1.67 & 24.07 & 8.4 & 1338 & 8.5 & 1630.8 \\
\hline $\mathbf{T}_{\mathbf{3}}$ & $\begin{array}{l}\text { Metribuzen@250g/ha + Oxyflorfen @125 } \\
\text { g/ha (PRE) }\end{array}$ & 57.60 & 1.60 & 22.93 & 7.3 & 1546 & 8.3 & 1245.3 \\
\hline $\mathbf{T}_{4}$ & $\begin{array}{l}\text { Pendimethalin @ } 1 \text { kg/ha (PRE) + } \\
\text { Metsulfuron methyl @ 4g/ha at } 25 \text { DAS } \\
\text { (POS) }\end{array}$ & 58.27 & 1.47 & 18.00 & 8.0 & 1858 & 7.8 & 1425.3 \\
\hline $\mathbf{T}_{5}$ & $\begin{array}{l}\text { Imazethapyr 10EC @ 75g /ha at 2-3 leaf } \\
\text { stage of weeds (POS) }\end{array}$ & 55.93 & 1.44 & 17.73 & 7.0 & 1835 & 7.6 & 1201.6 \\
\hline $\mathbf{T}_{6}$ & $\begin{array}{l}\text { Oxyflourfen @ } 125 \mathrm{~g} / \text { ha at 2-3 leaf stage of } \\
\text { weeds (POS) }\end{array}$ & 52.67 & 1.27 & 15.60 & 6.8 & 1705 & 7.0 & 1193.8 \\
\hline $\mathbf{T}_{7}$ & $\begin{array}{l}\text { Metsulfuron methyl @ } 4 \mathrm{~g} / \mathrm{ha} \text { at 2-3 leaf } \\
\text { stage of weeds (POS) }\end{array}$ & 54.73 & 1.33 & 16.27 & 6.6 & 1718 & 7.6 & 1055.6 \\
\hline $\mathbf{T}_{8}$ & $\begin{array}{l}\text { Isoproturon @ } 1 \mathrm{~kg} / \mathrm{ha} \text { at } 2-3 \text { leaf stage of } \\
\text { weeds (Post emergence) }\end{array}$ & 57.07 & 1.53 & 21.53 & 7.1 & 1374 & 8.1 & 1231.6 \\
\hline $\mathbf{T}_{9}$ & $\begin{array}{l}\text { Isoproturon @ } 1 \mathrm{~kg} / \mathrm{ha}+\text { Metsulfuron methyl } \\
@ 4 \mathrm{~g} / \mathrm{ha} \text { at } 2-3 \text { leaf stage of weeds (POS) }\end{array}$ & 55.60 & 1.47 & 16.73 & 7.5 & 1511 & 7.7 & 1309.7 \\
\hline \multirow[t]{3}{*}{$\mathbf{T}_{10}$} & $\begin{array}{l}\text { Oxadiargyl @ 80g/ha at 2-3 leaf stage of } \\
\text { weeds (POS) }\end{array}$ & 54.30 & 1.3 & 15.8 & 6.3 & 1420 & 7.5 & 1185.6 \\
\hline & $\mathrm{SE}(\mathrm{m}) \pm$ & 1.43 & 0.07 & 1.91 & 0.32 & 125.05 & 0.3 & 51.33 \\
\hline & C.D.(0.05) & 4.18 & 0.21 & 5.60 & 0.79 & NS & 0.9 & 150.56 \\
\hline
\end{tabular}


Table.2 Effect of different herbicides on Weed Density $\mathrm{m}^{-2}$, Weed dry weight $\mathrm{m}^{-2}(\mathrm{~g})$, Weed control efficiency (\%), Weed index of linseed under irrigated conditions. (Mean of two years)

\begin{tabular}{|c|c|c|c|c|c|c|c|c|}
\hline \multirow[t]{2}{*}{ S. No. } & \multirow[t]{2}{*}{ Treatment } & \multicolumn{2}{|c|}{ Weed Density $\mathbf{m}^{-2}$} & \multicolumn{2}{|c|}{$\begin{array}{c}\text { Weed dry weight } \mathrm{m}^{-2} \\
\text { (g) }\end{array}$} & \multicolumn{2}{|c|}{$\begin{array}{l}\text { Weed control efficiency } \\
(\%)\end{array}$} & \multirow[t]{2}{*}{ Weed index } \\
\hline & & 20 DAS & 80 DAS & 20 DAS & 80 DAS & 20 DAS & 80 DAS & \\
\hline $\mathbf{T}_{1}$ & Weedy Check & $\begin{array}{c}7.34 \\
(53.00)^{*}\end{array}$ & $\begin{array}{c}11.89 \\
(140.45)\end{array}$ & $\begin{array}{c}7.10 \\
(49.38)\end{array}$ & $\begin{array}{c}14.09 \\
(197.53)\end{array}$ & 0.0 & 0.0 & 33.31 \\
\hline $\mathbf{T}_{2}$ & Hand Weeding 20 DAS and 40 DAS & $\begin{array}{c}2.52 \\
(5.33)\end{array}$ & $\begin{array}{c}3.89 \\
(14.13)\end{array}$ & $\begin{array}{c}2.82 \\
(6.96)\end{array}$ & $\begin{array}{c}4.34 \\
(17.83)\end{array}$ & 58.3 & 66.2 & 0.00 \\
\hline $\mathbf{T}_{\mathbf{3}}$ & $\begin{array}{l}\text { Metribuzen@250g/ha + Oxyflorfen } \\
\text { @125g/ha (PRE) }\end{array}$ & $\begin{array}{c}5.63 \\
(30.67)\end{array}$ & $\begin{array}{c}9.07 \\
(81.27)\end{array}$ & $\begin{array}{c}4.08 \\
(15.66)\end{array}$ & $\begin{array}{c}7.98 \\
(62.62)\end{array}$ & 42.5 & 43.4 & 23.64 \\
\hline $\mathbf{T}_{4}$ & $\begin{array}{l}\text { Pendimethalin@ } 1 \mathrm{~kg} / \mathrm{ha}(\mathrm{PRE})+ \\
\text { Metsulfuron methyl @ 4g/ha at } 25 \text { DAS } \\
\text { (POS) }\end{array}$ & $\begin{array}{c}4.60 \\
(23.00)\end{array}$ & $\begin{array}{c}7.84 \\
(60.95)\end{array}$ & $\begin{array}{c}3.20 \\
(9.27)\end{array}$ & $\begin{array}{c}6.17 \\
(37.07)\end{array}$ & 54.9 & 56.2 & 12.60 \\
\hline $\mathbf{T}_{5}$ & $\begin{array}{l}\text { Imazethapyr 10EC @ } 75 \mathrm{~g} / \text { ha at 2-3 leaf } \\
\text { stage of weeds (POS) }\end{array}$ & $\begin{array}{c}6.30 \\
(38.67)\end{array}$ & $\begin{array}{c}10.17 \\
(102.47)\end{array}$ & $\begin{array}{c}4.28 \\
(17.33)\end{array}$ & $\begin{array}{c}8.96 \\
(79.32)\end{array}$ & 39.7 & 36.4 & 26.32 \\
\hline$T_{6}$ & $\begin{array}{l}\text { Oxyflourfen @ } 125 \mathrm{~g} / \mathrm{ha} \text { at 2-3 leaf stage } \\
\text { of weeds (POS) }\end{array}$ & $\begin{array}{c}6.37 \\
(39.67)\end{array}$ & $\begin{array}{c}10.29 \\
(105.12)\end{array}$ & $\begin{array}{c}4.78 \\
(21.88)\end{array}$ & $\begin{array}{c}9.93 \\
(97.51)\end{array}$ & 32.7 & 29.5 & 26.80 \\
\hline $\mathbf{T}_{7}$ & $\begin{array}{l}\text { Metsulfuron methyl @ } 4 \mathrm{~g} / \text { ha at 2-3 leaf } \\
\text { stage of weeds (POS) }\end{array}$ & $\begin{array}{c}7.23 \\
(51.33)\end{array}$ & $\begin{array}{c}11.67 \\
(136.03)\end{array}$ & $\begin{array}{c}6.45 \\
(40.67)\end{array}$ & $\begin{array}{c}12.78 \\
(162.67)\end{array}$ & 9.2 & 9.3 & 35.27 \\
\hline $\mathbf{T}_{8}$ & $\begin{array}{l}\text { Isoproturon @ } 1 \mathrm{~kg} / \mathrm{ha} \text { at } 2-3 \text { leaf stage of } \\
\text { weeds (Post emergence) }\end{array}$ & $\begin{array}{c}6.83 \\
(45.67)\end{array}$ & $\begin{array}{c}11.05 \\
(121.02)\end{array}$ & $\begin{array}{c}5.23 \\
(26.41)\end{array}$ & $\begin{array}{c}12.31 \\
(150.63)\end{array}$ & 26.3 & 12.6 & 24.48 \\
\hline $\mathbf{T}_{9}$ & $\begin{array}{l}\text { Isoproturon @ } 1 \text { kg/ha + Metsulfuron } \\
\text { methyl @ } 4 \mathrm{~g} / \mathrm{ha} \text { at } 2-3 \text { leaf stage of weeds } \\
\text { (POS) }\end{array}$ & $\begin{array}{c}5.16 \\
(25.67)\end{array}$ & $\begin{array}{c}8.31 \\
(68.02)\end{array}$ & $\begin{array}{c}3.33 \\
(10.13)\end{array}$ & $\begin{array}{c}6.44 \\
(40.53)\end{array}$ & 53.1 & 54.3 & 19.69 \\
\hline $\mathbf{T}_{\mathbf{1 0}}$ & $\begin{array}{l}\text { Oxadiargyl @ 80g/ha at 2-3 leaf stage of } \\
\text { weeds (POS) }\end{array}$ & $\begin{array}{c}6.71 \\
(44.00)\end{array}$ & $\begin{array}{c}10.84 \\
(116.60)\end{array}$ & $\begin{array}{c}5.17 \\
(25.73)\end{array}$ & $\begin{array}{c}10.17 \\
(102.91)\end{array}$ & 27.2 & 27.8 & 27.30 \\
\hline & $\mathrm{SE}(\mathrm{m}) \pm$ & 3.74 & 6.26 & 1.06 & 5.70 & - & - & - \\
\hline & C.D.(0.05) & 10.97 & 18.35 & 3.11 & 16.72 & - & - & - \\
\hline
\end{tabular}

* The values in parenthesis are original values and subjected to $\sqrt{x}+1$ transformation 
Table.3 Effect of different herbicides on economics of linseed under irrigated conditions. (Mean of two years)

\begin{tabular}{|c|c|c|c|c|c|}
\hline S. No. & Treatment & $\begin{array}{c}\text { Cost of } \\
\text { cultivation } \\
\text { (Rs /ha.) }\end{array}$ & GMR (Rs./ha.) & $\begin{array}{l}\text { NMR } \\
\text { (Rs./ha.) }\end{array}$ & $\begin{array}{l}\text { B:C } \\
\text { ratio }\end{array}$ \\
\hline $\mathbf{T}_{1}$ & Weedy Check & 21800 & 48942 & 27142 & 2.2 \\
\hline $\mathbf{T}_{2}$ & Hand Weeding 20 DAS and 40 DAS & 28250 & 73386 & 45136 & 2.6 \\
\hline $\mathbf{T}_{3}$ & Metribuzen@250g/ha + Oxyflorfen @125 g/ha (PRE) & 24100 & 56039 & 31939 & 2.3 \\
\hline $\mathbf{T}_{4}$ & $\begin{array}{l}\text { Pendimethalin @ } 1 \text { kg/ha (PRE) + Metsulfuron methyl @ 4g/ha at } 25 \\
\text { DAS (POS) }\end{array}$ & 23200 & 64139 & 40939 & 2.8 \\
\hline $\mathbf{T}_{5}$ & Imazethapyr 10EC @ 75g /ha at 2-3 leaf stage of weeds (POS) & 22200 & 54072 & 31872 & 2.4 \\
\hline $\mathbf{T}_{6}$ & Oxyflourfen@125 g/ha at 2-3 leaf stage of weeds (POS) & 22900 & 53721 & 30821 & 2.3 \\
\hline $\mathbf{T}_{7}$ & Metsulfuron methyl @ 4 g/ha at 2-3 leaf stage of weeds (POS) & 22500 & 47502 & 25002 & 2.1 \\
\hline $\mathbf{T}_{8}$ & Isoproturon@1 kg/ha at 2-3 leaf stage of weeds (Post emergence) & 22700 & 55422 & 32722 & 2.4 \\
\hline $\mathbf{T}_{9}$ & $\begin{array}{l}\text { Isoproturon @ } 1 \mathrm{~kg} / \mathrm{ha}+\text { Metsulfuron methyl @ } 4 \mathrm{~g} / \mathrm{ha} \text { at 2-3 leaf } \\
\text { stage of weeds (POS) }\end{array}$ & 22950 & 58937 & 35987 & 2.6 \\
\hline $\mathbf{T}_{10}$ & Oxadiargyl @ 80g/ha at 2-3 leaf stage of weeds (POS) & 22100 & 53355 & 31255 & 2.4 \\
\hline
\end{tabular}


The methods of weed management had significant effect on weed density of different species of weeds, weed dry weight, weed control efficiency and weed index. All treatments significantly reduced the weed density of all the species of weed compared to control (Weedy check) (Table 2). Among the herbicide treatments application of Pendimethalin @ 1 kg/ha (PRE) + Metsulfuron methyl @ 4g/ha at 25 DAS (POS) $\mathrm{T}_{4}$ proved significant and recorded lowest weed density, weed dry weight, weed control efficiency at $20 \& 80$ DAS. Total weed dry weight and weed control efficiency was in direct proportion to weed density i.e. lesser the weed density, lesser was the total weed dry weight, weed control efficiency and vice-versa. This is due to the effect of pendimethalin in inhibiting cell division and cell elongation which resulted in death of weeds shortly after germination and metsulfuron-methyl is a residual sulfonylurea compound. It is a systemic compound with foliar and soil activity and it works rapidly after it is taken up by the plant which inhibit cell division in the shoots and roots of the plant, and it is biologically active at low use rates.

Weed index indicating yield reduction due to weed competition, was the highest in weedycheck while it was the lowest in weedy check. The highest weed index in weedy-check was due to unchecked weed growth throughout the crop growth period and the consequent competition for growth resources resulted in the lowest yield with the treatment.

Among the herbicide treatments lowest weed index was recorded with Pendimethalin @ 1 kg/ha (PRE) + Metsulfuron methyl @ 4g/ha at 25 DAS (POS) $\mathrm{T}_{4}$. This showed the efficiency of combined application of these herbicides as pre-emergence for managing weeds in linseed field without much reduction in yield.

\section{Effect on economics}

The net income per hectare was directly associated with the productivity of crop under applied resources (Table 3). In the present investigation, the highest net income, next to hand weeding twice, was obtained from $\mathrm{T}_{4}$ i.e. Pendimethalin @ $1 \mathrm{~kg} / \mathrm{ha}$ (PRE) + Metsulfuron methyl @ 4g/ha at 25 DAS (POS) up to Rs.40939/ha with B:C ratio 2.8. Similar findings were reported by Mahajan, (2017). Whereas, Despite having high net returns under hand weeding twice $\mathrm{T}_{2} \mathrm{~B}: \mathrm{C}$ (2.6) ratio was less due to the extra input cost and labours involved in weeding. The lowest income Rs.27142/ha and B:C ratio 1.8 was recorded from the control.

On the basis of present investigation, it is concluded that the pre- emergence application of pendimethalin @ $1 \mathrm{~kg} / \mathrm{ha} f b$ application of metsulfuron methyl @ 4g/ha at 25 DAS in linseed grow under irrigated condition responded well in terms of effective weed control and obtaining higher yield.

\section{References}

Anonymous 2019. Agricultural Statistics at a Glance 2019. Government of India. Ministry of Agriculture and Farmers Welfare. www.agricoop.nic.in \& http:// eands.dacnet.nic.in.

Bhatt, P. S., M. Yakadri, M. Madhavi, S. Sridevi and P. L. Rani. 2020. Bioefficacy of herbicide combinations for control of weeds in Crop Protection transplanted rice (Oryza sativa). Indian Journal of Agricultural Sciences 90 (4): 717-20.

Gaurav Mahajan. Analysis of cost and returns of kodo millet production under rainfed condition of Kymore plateau and Satpura hill region. 2017. Bioved, 28(2): 315-320.

Gaurav Mahajan. Bio efficiency of new 
herbicides for weed management in linseed (Linum usitatissimum L.) under irrigated conditions. In: 3rd National Convention: Agrivision 2018 on "Resource Conservation for Sustainable Agriculture and Food Security" 24-25th March. 2018. New Delhi. Pp 21-23.

Preeti Tripathi, Gaurav Mahajan and R. K. Tiwari. 2016. Effect of different methods of crop establishment and weed control measures on little millet
(Panicum sumatrense) under rainfed condition. The Bioscan. 11(3): 16331636.

Rakesh Kumar, U.P. Singh and Gaurav Mahajan. 2017. Residue and weed management practices in zero-till wheat (Triticum aestivum L.) under rice-wheat cropping system. International Journal of Agriculture Sciences. 9(4): 37083712.

\section{How to cite this article:}

Gaurav Mahajan and Deepak Khande. 2020. Bio-efficacy of Pre- and Post-emergence Herbicides for Weed Management in Linseed (Linum usitatissimum L.) under Irrigated Conditions. Int.J.Curr.Microbiol.App.Sci. 9(08): 3153-3160.

doi: https://doi.org/10.20546/ijcmas.2020.908.359 